\title{
Correction to: Pakistan Randomized and Observational Trial to Evaluate Coronavirus Treatment (PROTECT) of Hydroxychloroquine, Oseltamivir and Azithromycin to treat newly diagnosed patients with COVID-19 infection: A structured summary of a study protocol for a randomized controlled trial
}

\author{
Javed Akram ${ }^{1}$, Shehnoor Azhar ${ }^{2 *}$, Muhammad Shahzad ${ }^{3}$, Waqas Latif ${ }^{4}$ and Khalid Saeed Khan ${ }^{5}$
}

Correction to: Trials 21, 702 (2020)

https://doi.org/10.1186/s13063-020-04616-4

Following publication of the original article [1], we were notified that the authors would like to modify the article title to "Pakistan Randomized and Observational Trial to Evaluate Coronavirus Treatment (PROTECT) of Hydroxychloroquine, Oseltamivir and Azithromycin to treat newly diagnosed patients with COVID-19 infection: A structured summary of a study protocol for a randomized controlled trial", as it is conceptually and grammatically more accurate and reflective of the nature and topic.

\section{Author details}

${ }^{1}$ Vice Chancellor/Professor of Internal Medicine, University of Health Sciences, Lahore, Pakistan. ${ }^{2}$ Assistant Professor Public Health, University of Health Sciences, Lahore, Pakistan. ${ }^{3}$ Professor of Pharmacology, University of Health Sciences, Lahore, Pakistan. ${ }^{4}$ Data Analyst at University of Health Sciences,
Lahore, Pakistan. ${ }^{5}$ Distinguished Investigator at Department of Preventive Medicine and Public Health, University of Granada, Granada, Spain.

Published online: 22 August 2020

Reference

1. Akram, et al. Pakistan Randomized and Observational Trial to Evaluate Coronavirus Treatment (PROTECT) of Hydroxychloroquine, Oseltamivir and Azithromycin to treat newly diagnosed patients with COVID-19 infection who have no comorbidities like diabetes mellitus: A structured summary of a study protocol for a randomized controlled trial. Trials. 2020;21:702. https://doi.org/10.1186/s13063-020-04616-4.

The original article can be found online at https://doi.org/10.1186/s13063020-04616-4.

* Correspondence: shehnoor.azhar@gmail.com

${ }^{2}$ Assistant Professor Public Health, University of Health Sciences, Lahore, Pakistan

Full list of author information is available at the end of the article

(c) The Author(s). 2020 Open Access This article is licensed under a Creative Commons Attribution 4.0 International License, which permits use, sharing, adaptation, distribution and reproduction in any medium or format, as long as you give appropriate credit to the original author(s) and the source, provide a link to the Creative Commons licence, and indicate if changes were made. The images or other third party material in this article are included in the article's Creative Commons licence, unless indicated otherwise in a credit line to the material. If material is not included in the article's Creative Commons licence and your intended use is not permitted by statutory regulation or exceeds the permitted use, you will need to obtain permission directly from the copyright holder. To view a copy of this licence, visit http://creativecommons.org/licenses/by/4.0/ The Creative Commons Public Domain Dedication waiver (http://creativecommons.org/publicdomain/zero/1.0/) applies to the data made available in this article, unless otherwise stated in a credit line to the data. 